\title{
Review Article \\ The Effect of Exchange Rate Movements on Trade Balance: A Chronological Theoretical Review
}

\author{
Dhakir Abbas Ali, Fuadah Johari, and Mohammad Haji Alias \\ Faculty of Economics and Muamalat, Universiti Sains Islam Malaysia (USIM), 71800 Nilai, Negeri Sembilan, Malaysia \\ Correspondence should be addressed to Fuadah Johari; fuadah@usim.edu.my
}

Received 10 April 2014; Revised 2 August 2014; Accepted 3 August 2014; Published 24 August 2014

Academic Editor: Udo Broll

Copyright ( 2014 Dhakir Abbas Ali et al. This is an open access article distributed under the Creative Commons Attribution License, which permits unrestricted use, distribution, and reproduction in any medium, provided the original work is properly cited.

\begin{abstract}
This paper evaluates the current state of the literature concerning the effects of exchange rate movements on trade balance. Thus, this paper is a review article and provides a survey of the alternative theories that focus on the effect of exchange rate changes on the trade balance. It systemizes the literature into four distinct reviews and approaches following the chronological order. The paper presents the (a) Standard Theory of International Trade, (b) Elasticity Approach, (c) Keynesian Absorption Approach, and (d) Monetary Approach. The study shows that higher attention should be given for the most plausible dynamic theory in this field, known as the J-Curve.
\end{abstract}

\section{Introduction}

As one of the widely used economic indicators, real exchange rate can be simply defined as the nominal exchange rate that takes inflation differentials among countries into account [1]. In international trade, its importance stems from the fact that it reflects the trade competitiveness [2]. However, it is still widely used in many fields of economics for purposes other than trade. Real exchange rate movements affect many economic variables; where some studies covered the relation with foreign direct investment [3], some other studies focused on the effect on tourism [4] or, even more generally, on economic growth [5].

The significance of the real exchange rate for a central bank stems mainly from its effects on the Central Bank's balance sheet, thus, on its ability to conduct a prudent monetary policy. A change in real exchange rate leads to variations in short-run capital flows. As a result, these fluctuations would then have an effect on the Central Bank's net foreign assets [6] . As basically illustrated above, by controlling the real exchange rate, a chain of economic effects takes place. However, this study is chiefly concerned with its effects on international trade.

For a long time, economists have stressed on the relation between exchange rate and trade balance. However, since the middle of the twentieth century and due to the developments in macroeconomic and econometric analysis, some studies started to present some empirical results. Even with the presence of trade data, the issue has remained highly debated and no consensus was reached.

This study investigates the state of the literature from a new perspective. It systemizes the explanations provided in empirical studies into distinctive theoretical approaches. A special focus is given to the J-Curve phenomenon since it is accepted as the most plausible among all and provides indirect methods to test for other approaches [7].

This study is organized as follows: Section 2 opens by a concise recap of the definitions of real exchange rate; it then descends to the literature review of the topic following the chronological order whenever applicable. The study is concluded in Section 3.

\section{The Impact of Exchange Rate Movements on Trade Balance}

The various definitions of the real exchange rate can be mainly grouped into two main categories. The first category of definitions is made in line with the purchasing power parity (PPP), while the second is based on the distinction between the tradable and the nontradable goods. Although they might 
coincide in some very special cases, these definitions usually give different results when employed in empirical studies.

According to the PPP-based definition, the real exchange rate $\left(r_{\mathrm{ppp}}\right)$ is defined in the long-run as the nominal exchange rate $(e)$ after adjustment to the ratio of the foreign price level $\left(p_{f}\right)$ to the domestic price level $(p)$. Mathematically, it is given by

$$
r_{\mathrm{ppp}}=e \frac{p_{f}}{p} .
$$

In this definition, the decline in $\left(r_{\mathrm{ppp}}\right)$ is interpreted as the real appreciation of the domestic currency, since it indicates that few units of the domestic currency are needed to purchase the same one unit of foreign currency.

On the other hand, the tradable/nontradable based definition takes the relative price of the tradables and nontradables in a country as an indicator for the level of competitiveness in international trade. The rationale behind this definition is that the cost differential between countries is interrelated with the relative price structures in these economies. Under the assumption that prices of the tradables will be equal all around the world through trade, the real exchange rate defined on the basis of tradable and nontradable goods distinction can be mathematically represented as

$$
r_{r}=\frac{p_{t}}{p_{n}}=e \frac{p_{t}^{*}}{p_{n}^{*}} .
$$

In this specification, $p_{t}\left(p_{t}^{*}\right)$ stands for the domestic (international) price of tradables, while the prices of the nontradables are denoted by $p_{n}$. Thus, the fall of $r_{r}$ in this definition also indicates real appreciation of domestic currency [6].

Both definitions stated above rely on the assumption that home country has only one trading partner. However, in some empirical studies, such an assumption might be invalid. By considering this fact, we can distinguish a third definition called the real effective exchange rate. In REER definition, the real exchange rate corresponds to a group of countries instead of one partner only. Following some weighting criteria, the share of the bilateral trade to total trade volume or the share of the currencies used in the international trade transactions can be given as examples of these weighting criteria [8].

By stating these differing definitions of real exchange rate, it should be noted that some studies have discussed the role of nominal exchange rate on trade balance instead of the real exchange rate. This difference is mainly due to whether the country follows a pigged or free-floating exchange rate regime. Thus, the reader should understand the theories stated in this study in line with these definitions. However, regardless the definition of the real exchange rate, it is believed to affect the competiveness of a country's merchandise. Different empirical and theoretical studies have investigated the effect of exchange rate movements on trade balance. The next section systemizes these studies into four broad approaches to ease the understanding of the historical improvement of the topic.

\section{Research Method}

This paper is theoretical in nature and specifically a review article on the determinants effect of exchange rate movement on the trade balance. It provides a survey of the alternative theories that focus on the effect of exchange rate changes on the trade balance. It systemizes the literature into four distinct reviews and approaches following the chronological order. The paper presents (a) Standard Theory of International Trade, (b) Elasticity Approach, (c) Keynesian Absorption Approach, and (d) Monetary Approach. Data and information are collected through the libraries and recognized journals both local and international. This simply suggests that secondary sources are predominantly used in the methodology of this study. The next section systemizes these studies into four different reviews and approaches of exchange rate movements on trade balance to ease the understanding of the historical improvement of the topic.

\section{The Determinants Effect of Exchange Rate on Trade Balance: The Reviews and Approaches}

4.1. Standard Theory of International Trade. During the sixteenth to eighteenth centuries, Mercantilism was the dominant economic system of most industrial countries. The Mercantilist approach to international trade assumed that the wealth of a nation depends chiefly on its ability to possess precious metals such as gold and silver. The possession of those metals took place through supporting exports and encouraging metal discoveries in the Americas and, on the other hand, suppressing imports through imposing excessive tariffs [9]. After almost three centuries of instability and economic failure, Mercantilism was strongly criticized by what became to be known later as the Standard Theory of International Trade [10]. Tracing back the evolution of the Standard Theory, one goes back to the years 1776 and 1817, which, respectively, marked the publications of Adam Smith's Wealth of Nations [11] and David Ricardo's on the principles of Political Economy and Taxation [12]. The two books heralded the formulation of a theory of free trade, based on the unprecedented success of England in the respective fields of industry and trade [13].

Standard Trade Theory relates merchandise with the movements of real exchange rate following a simple common sense approach. Setting all other variables fixed, a fluctuation in exchange rate affects both the value and volume of trade. If real exchange rate increases in home country, that is, real depreciation, the households can get less imported goods in exchange for a unit of domestic goods and services. Thereby, a unit of imported goods would give higher number of units of domestic goods. Eventually, domestic households buy fewer imports while foreign households purchase relatively more domestic goods. Ultimately, the higher the real exchange rate for the home country, the more the trade surplus the country obtains [14].

Lerner further extended the typical trade theory by accounting for demand price elasticities of imports and 


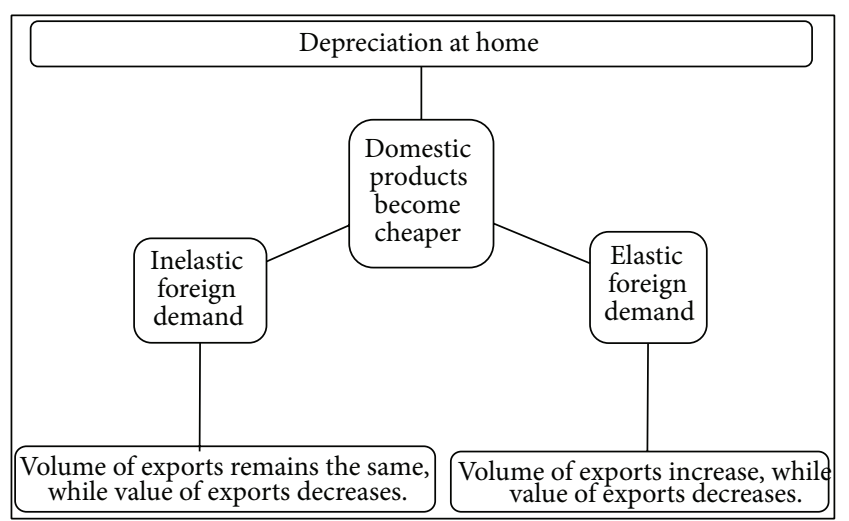

Figure 1: Elasticities approach (the case foreign demand).

exports as instrumental elements in measuring the effect of real exchange rate variations on trade balance. Thus, a rise in exports and a reduction in imports due to depreciation in real exchange rate do not necessarily mean a correction of trade balance deficit. According to Lerner, trade balance is not concerned with the volume of physical goods but with their actual values [15].

\subsection{Elasticities Approach, Marshall-Lerner Condition, and J-} Curve Theory. In elasticities approach, trade balance adjustment path is viewed on the basis of elasticities of demand for imports and exports. The elasticity of demand is defined as the quantity responsiveness of demanded goods or services to changes in price [16]. Although the Elasticity Approach is commonly known as Bickerdike-Robinson-Metzler Condition [17], Bickerdike [18] was actually the one who originally developed and laid the foundations of this approach by modeling nominal import and export prices as functions of import and export quantities [19, 20]. Later Robinson [21] and Metzler [22] contributed to the elasticities approach by clarifying and detailing Bickerdike's novel ideas.

Bickerdike-Robinson-Metzler Condition implies that the change in the foreign currency value of the trade balance depends upon the import and export supply and demand elasticities and the initial volume of trade. As can be seen, all discussions in the elasticities approach revolve around the questions of volume and value responses to changes in real exchange rate. Figure 1 summarizes the case of domestic elasticity of supply in a devaluating country.

As shown, the same logic also applies to the domestic demand. However, as depicted in Figure 1, lower prices in the domestic country as a result of currency devaluation will normally increase foreign demand for domestic goods, but only when foreign demand is elastic. On the other hand, if foreign demand elasticity for domestic goods is weak, the quantity of domestic goods will not rise to the extent that it exceeds the decline in the value of exports caused by the cheaper prices [23]. Following the same notions, the case of domestic elasticity of demand can be understood in the same context. If domestic demand for foreign goods is elastic, the change in prices in the domestic market will lead to a change in the domestic consumer's behavior. The consumers will

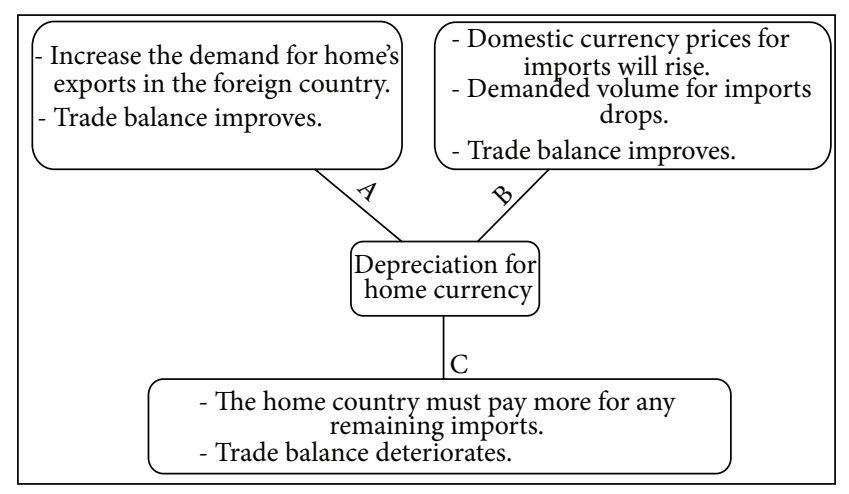

FIGURE 2: Marshall-Lerner Condition.

then compensate by consuming domestic rather than foreign goods forcing the value of imports to decline. In summary, if the decline in value of domestic imports is greater than the decline in value of domestic exports, the trade balance will improve.

Policymakers apply the Elasticity Approach in reality when a country faces trade balance deficit. They would have to consider the responsiveness of imports and exports for a change in exchange rate to measure to which extent devaluation would affect the trade balance. However, if foreign and domestic demands for imports and exports are elastic, a small change in the spot exchange rate might have substantial impact on trade balance [24].

Marshall-Lerner Condition is a further extension of the elasticities approach. The condition could be seen as an implication of the work of Bickerdike [18]. Nevertheless, it was named after Alfred Marshall who was born in 1842 and died in 1924, since he is considered as the father of the elasticity as a concept and Lerner [15] for his later exposition of it [19]. According to this approach, if monetary policymakers depreciate the currency with the intention of improving trade balance, the demand for the nation's exports and imports should be adequately elastic. Assuming trade in services, investment-income flows, and unilateral transfers are equal to zero, so that the trade account is equal to the current account, Marshall-Lerner Condition states that the sum of the absolute values of the two elasticities must exceed unity [25]. Conversely, if the sum is less than one, trade balance worsens when a depreciation takes place [15].

In distinction from Bickerdike's approach, MarshallLerner Condition is based chiefly on two assumptions. The first is that trade was initially balanced when exchange rate depreciation took place, so that the foreign currency value of exports equals the foreign currency value of imports. Second and most importantly, prices are fixed in seller's currencies; thus, the supply elasticities are infinite. The effect can be explained as depicted in Figure 2.

Following a currency depreciation, the trade balance is to improve only when the volume effect shown in $\mathrm{A}$ and $\mathrm{B}$ outweighs the price effect denoted as $\mathrm{C}$. Thus, $\mathrm{ML}=(\mathrm{A}+\mathrm{B})$ $>$ (C) [26]. 
However, the Marshall-Lerner Condition is also indicative of stability. If the sum of the two import and export demand elasticities does not exceed unity, the equilibrium is unstable and an economic model with an unstable equilibrium could be inefficient for measuring the outcome of exchange rate depreciation on trade [27].

Almost three decades after the generalization of the Marshall-Lerner Condition, the J-Curve theory came into existence. As first illustrated by Magee [28], the J-Curve phenomenon reflects how a devaluation of a country's exchange rate affects its trade balance over time. Thus, it is considered as a dynamic view of Marshall-Lerner Condition [29] or, more generally, the elasticities approach. In the short-run, instantly after currency devaluation, domestic importers face inflated import prices as paid in domestic currency; thus, the net exports decline. On the other hand, the domestic exporters in the devaluating country face lower export prices since the demand for exports and imports is fairly inelastic in the short-run. This inelasticity of demand is caused by the sluggishness in the change of consumer's behavior and the lag of renegotiating deals. In other words, in the shortrun when prices are relatively constant the balance of trade faces a decline due to the stickiness of prices and sluggishness to demand change. Prices stickiness is when goods are still traded at the price levels prior to devaluation [30]. The trade balance worsens by the value of total imports in foreign currency multiplied by the magnitude of the rise in the price of foreign currency since contracts made before the depreciation force fixed prices and volumes. The short-run period is commonly known as the "exchange rate passthrough period."

Afterwards, domestic demand starts to shift from foreign to domestic production of substitution goods as a reaction to the higher prices of imports, causing a trade balance improvement. Furthermore, the markets in home country experience an increase in exports volume due to the decrease in exports prices. The period of these two long-run factors is commonly known as the "volume adjustment period" and they have a favorable impact on trade balance [31]. However, the J-Curve phenomenon predicts the trade balance to improve in the long-run to a higher level compared to its level before depreciation. The dynamic reaction of trade balance as a short-run dip and long-run recovery takes the shape of the flattened J letter, hence the J-Curve phenomenon. The JCurve is depicted in Figure 3.

As an implication on monetary policy, the exchange rate devaluation should be sufficiently large to have a favorable long-run impact on trade balance. In relation to MarshallLerner Condition, if trade balance improves in the long-run due to currency devaluation to a level higher than the level before devaluation under the J-Curve assumptions, we can consider the Marshall-Lerner Condition fully satisfied [7]. If not, the Marshall-Lerner Condition is not satisfied and the JCurve is expected to flatten on lower level compared to the level before devaluation [32].

The time frame for the J-Curve, before the MarshallLerner Condition kicks in and improves the trade balance, is said to be anytime between a few months to two or three years $[30,33]$.

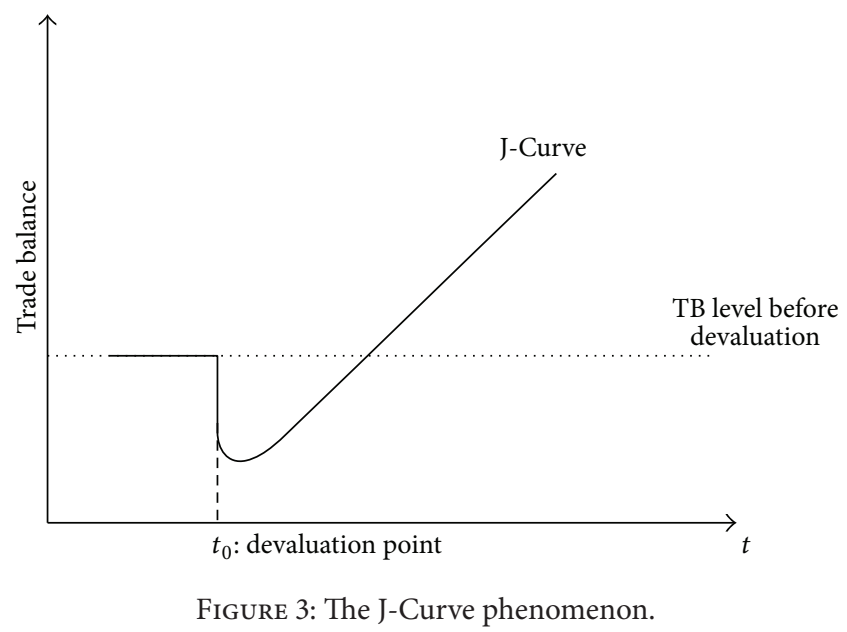

4.3. Keynesian Absorption Approach. The approach of elasticity is mainly criticized for being a partial equilibrium approach which does account for the macroeconomic effects arising from price changes and production fluctuations in response to currency devaluation [34]. In fact, it only accounts for the value and volume responses to price changes. On the other hand, in the absorption and Monetary Approaches, depreciation is related to macroeconomic variables that usually undermine the favorable impact of the exchange rate devaluation on the trade balance. The Absorption Approach merges the elasticities approach with the Keynesian macroeconomics. It was formally modeled in early 1950s by Meade [35], Alexander [36], and others.

This approach starts with the assumption that a nation's expenditures fall into four categories: consumption $(c)$, investment $(i)$, government expenditures $(g)$, and imports $(m)$. All variables are measurements in real terms since this approach treats prices as constant. The sum of these four categories is also referred to as Domestic Absorption (a):

$$
a \equiv c+i+g+m .
$$

On the other hand, a nation's real income $(y)$ equals its total expenditures on output, where $x$ is real exports; real income is expressed as

$$
y \equiv c+i+g+x .
$$

A nation's current account balance equals the difference between real income $(y)$ and absorption $(a)$, which can be written as

$$
y-a=(c+i+g+x)-(c+i+g+m)=x-m .
$$

Thus, the change in current account equals the change in real income minus the change in the sum of the remaining three variables, consumption, investment, and government expenditures, as follows:

$$
\Delta(x-m)=\Delta y-\Delta(c+i+g) .
$$

This indicates that the trade account improves only if domestic output growth exceeds domestic absorption [37]. A currency devaluation improves trade balance if the substitution 
towards domestic goods in response to the relative price change boosts output more than absorption. In reality, this is more likely to happen in an economy characterized by excess capacity where the Keynesian multiplier effect works [38]. In an economy near full employment, or one facing strong production bottlenecks, output is not likely to increase and the trade balance could improve only if absorption decreases. Inflationary pressures also undermine the relative price shifts that induce an increase in export production and a decline in consumption of imported goods [34].

In summary, trade balance under the Absorption Approach is a function of real income and absorption (domestic consumption) $T B=f(Y, A)$. Trade balance can improve if there is an increase in output $(Y)$ or a decrease in domestic consumption $(A)$ or both. Suppose $A$ is constant and the economy is not in full employment (mostly in developing countries); when currency devaluation occurs the ultimate effect is expected to be an increase in output, thus a trade balance improvement.

4.4. Monetary Approach. As mainly championed by the contributions of Harry Johnson and Jacob Frenkel in the early 1970s, nearly the same time the J-Curve theory emerged, the Monetary Approach suggests that devaluation should be understood in a monetary context. Thus, a balance of payments deficit is solely a monetary phenomenon mainly caused by excessive money supply [37]. Currency devaluation has an impact on the balance of payments only through its effect on real money supply. Therefore, a devaluation increases the balance of payment by increasing domestic prices and thereby reducing the real money supply. Devaluations fail if they are followed by further increases in the nominal money supply that reestablish the original disequilibrium. The long-run effect on the trade balance is thus ambiguous [38].

When a country devaluates currency, the real value of the money supply decreases due to the increase in prices of traded commodities and services measured in the domestic prices. Mathematically, this can be shown as

$$
\frac{M^{s}}{p}=M^{d}(Y, E),
$$

where $M^{s}$ is the nominal money supply, $M^{d}$ is money demand, $Y$ is income (output), and $E$ is the nominal exchange rate.

The relation can be summarized as follows: a devaluation in $E$ leads to an increase in the prices of traded goods and services and, therefore, lowers the real value of cash balance, which in turn, eventually causes a reduction in spending in order to restore the real value of its holdings of money. The decline in consumption results ultimately in a reduction in absorption and trade balance improvement.

Additionally, as argued by Johnson [39], an increase in money supply gives rise to the level of real balances; thus, individuals forecast their wealth to rise, causing the level of expenditures to increase relative to income and the trade balance to deteriorate. Thus, the effect of money supply on the balance of trade is negative. In the same context, Miles
[40] argues that the negative effect might not be observed in the following cases. First, the nominal money balance may be a small fraction of total wealth. Second, the private sector may not perceive money as net wealth. Third, response of expenditures to changes in wealth could be insignificant.

The most significant implication of the Monetary Approach is that if the monetary authorities expand money supply after devaluation to meet the new demand for money, the effect of devaluation is believed to be preserved. Some empirical studies argued that excess money supply might increase consumption and lower the trade balance $[41,42]$.

\section{Concluding Remarks}

This study systemized the theoretical literature on the effect of exchange rate movements on trade balance into four approaches, namely, (a) Standard Theory of International Trade, (b) Elasticity Approach, (c) Keynesian Absorption Approach, and (d) Monetary Approach. A special stress on the chronological order of appearance and development of each approach was presented throughout the paper. Although some researchers point out that the four approaches mentioned above are all correct in essence [34], many differences in the plausibility and empirical applicability can still be seen as discussed in the following three points.

First, although the Standard Theory of International Trade provided fertile grounds and gave some basics for the latter approaches, the theory barely discussed the effects of exchange rate on trade balance and merely championed free trade through the principles of Absolute Advantage of Adam Smith and the Comparative Advantage of David Ricardo. Thus, the theory does not seem to be applicable to today's much more complicated circumstances. Additionally, this approach seems to be at odds with the Monetary Approach in a specific aspect; that is, the latter disagrees with the claim that exchange rate depreciation can improve trade balance perpetually as explained above. Moreover, all other approaches disagree with the Standard Trade Theory in its claim that currency depreciation improves trade balance unconditionally.

Second, the Keynesian based Absorption Approach and the Monetary Approach both focus on the macroeconomic linkages and identities, rather than the microeconomic relationships of the Elasticity Approach. Thus, the relationship between the trade-exchange rate issue and other macroeconomic variables could be better understood under these two approaches. However, relatively few empirical studies investigated these two approaches. This might be due to the fact that both approaches were not substantially improved to cope with dramatic changes in the nature of the current account balance in post-Bretton Woods era, which left these two approaches underdeveloped and rudimentary.

Third, the Elasticity Approach, which was origanally triggered by the novel ideas of Bickerdike [18], and Marshall, and Groenewegen [23] and passed through several stages of improvement for almost half a century, can be considered as the most important breakthrough in the context of assessing the impact of exchange rate on trade balance [34]. This is reflected by the enormous number of empirical studies which 
investigated it. However, the dynamic view of this approach, the J-Curve theory, gained most of the attention [43]. In fact, by assessing all the theories mentioned above, one can conclude that the J-Curve is the most affluent among all for the reasons stated in the following:

(i) empirical testing for the J-Curve can indirectly test the approaches of elasticities and Marshall-Lerner Condition by evaluating the long- and short-run coefficients of the real exchange rate in the econometric analysis;

(ii) the J-Curve is the only approach which allows tracing the effect of real exchange rate depreciation on trade balance over time;

(iii) obtaining trade data for testing this theory is much easier than collecting data on volume and value of trade for assessing Marshall-Lerner Condition.

The reasons mentioned above make the J-Curve approach one of the most tested, yet debated, theories in the literature. The J-Curve provides vital information for monetary policymakers and economists [44].

\section{Conflict of Interests}

The authors declare that there is no conflict of interests regarding the publication of this paper.

\section{References}

[1] I. Al-Ezzee, "Real influences of real exchange rate and oil price changes on the growth of real GDP: case of Bahrain," International Proceedings of Economics Development \& Research, vol. 8, p. $155,2011$.

[2] M. Heun and T. Schlink, "Early warning systems of financial crises: implementation of a currency crisis model for Uganda," Working Paper Series, Frankfurt School of Finance \& Management, 2004.

[3] M. W. Klein and E. Rosengren, "The real exchange rate and foreign direct investment in the United States. Relative wealth vs. relative wage effects," Journal of International Economics, vol. 36, no. 3-4, pp. 373-389, 1994.

[4] A. Schiff and S. Becken, "Demand elasticity estimates for New Zealand tourism," Tourism Management, vol. 32, no. 3, pp. 564575, 2011.

[5] Y. Miao and A. Berg, The Real Exchange Rate and Growth Revisited: The Washington Consensus Strikes Back? International Monetary Fund, 2010.

[6] A. N. Kipici and M. Kesriyeli, The Real Exchange Rate Definitions and Calculations, Central Bank of the Republic of Turkey, Research Department Publication, 1997.

[7] R. S. Hacker and A. Hatemi-J, "The effect of exchange rate changes on trade balances in the short and long run," Economics of Transition, vol. 12, no. 4, pp. 777-799, 2004.

[8] N. Berman, P. Martin, and T. Mayer, "How do different exporters react to exchange rate changes?" Quarterly Journal of Economics, vol. 127, no. 1, pp. 437-492, 2012.

[9] H. Peukert, "Mercantilism," in Handbook of the History of Economic Thought, vol. 11 of The European Heritage in Economics and the Social Sciences, pp. 93-121, Springer, New York, NY, USA, 2012.
[10] C. Wilson, “The other face of mercantilism," Transactions of the Royal Historical Society, vol. 9, pp. 81-101, 1959.

[11] A. Smith, Wealth of Nations, University of Chicago Bookstore, 1776.

[12] D. Ricardo, Principles of Political Economy and Taxation, G. Bell \& sons, 1817.

[13] S. Sen, "International trade theory and policy: a review of the literature," Working paper, Levy Economics Institute, 2010.

[14] W.-B. Zhang, International Trade Theory: Capital, Knowledge, Economic Structure, Money, and Prices Over Time, Springer, 2008.

[15] A. Lerner, Economics of Control: Principle of Welfare Economics, Macmillan, New York, NY, USA, 1944.

[16] R. E. Howitt, W. D. Watson, and R. M. Adams, "A reevaluation of price elasticities for irrigation water," Water Resources Research, vol. 16, no. 4, pp. 623-628, 1980.

[17] C.-W. Hooy and T.-H. Chan, "Examining Exchange Rates Exposure, J-Curve and the Marshall-Lerner Condition for High Frequency Trade Series between China and Malaysia," 2008.

[18] C. F. Bickerdike, "The instability of foreign exchange," The Economic Journal, vol. 30, no. 117, pp. 118-122, 1920.

[19] T. J. Brooks, Currency Depreciation and the Trade Balance: An Elasticity Approach and Test of the Marshall-Lerner Condition for Bilateral Trade between the US and the G-7, The University of Wisconsin-Milwaukee, 1999.

[20] J. S. Chipman, "Bickerdike's theory of incipient and optimal tariffs," History of Political Economy, vol. 25, no. 3, pp. 461-492, 1993.

[21] J. Robinson, Essays in the Theory of Employment, Basil Blackwell, Oxford, UK, 1947.

[22] L. A. Metzler, "Stability of multiple markets: the Hicks conditions," Econometrica: Journal of the Econometric Society, vol. 13, no. 4, pp. 277-292, 1945.

[23] A. Marshall and P. D. Groenewegen, Money, credit \& commerce, 1923.

[24] J. Daniels and D. D. VanHoose, International Monetary and Financial Economics, 2005.

[25] W. B. Brown and J. S. Hogendorn, International Economics: in the Age of Globalization, University of Toronto Press, 2000.

[26] R. S. Hacker and H.-J. Abudlnasser, The Effect of Real Exchange Rate Changes on Trade Balances in the Short and Long Run: Evidence from German Trade With Transitional European Economies, 2002.

[27] J. Borkakati, International Trade: Causes and consequences, Macmillan, London, UK, 1998.

[28] S. P. Magee, "Currency contracts, pass-through, and devaluation," Brookings Papers on Economic Activity 303-325, 1973.

[29] J. Niehans, International Monetary Economics, Johns Hopkins University Press, Baltimore, Md, USA, 1984.

[30] M. Mackintosh, V. Brown, and N. Costello, Economics and Changing Economies, Open University Press, 1996.

[31] M. Gärtner, Macroeconomics under Flexible Exchange Rates, Harvester Wheatsheaf, 1993.

[32] B. Södersten and G. Reed, International Economics, MacMillian, London, UK, 3rd edition, 1994.

[33] D. Miles and A. Scott, Macroeconomics, Understanding the Wealth of Nations, Wiley, 2005.

[34] A. Kim, "An empirical analysis of Korea's trade imbalances with the US and Japan," Journal of the Asia Pacific Economy, vol. 14, no. 3, pp. 211-226, 2009. 
[35] J. Meade, "The removal of trade barriers: the regional versus the universal approach," Economica, vol. 18, no. 70, pp. 184-198, 1951.

[36] S. S. Alexander, "Effects of a devaluation on a trade balance," Staff Papers-International Monetary Fund, vol. 2, no. 2, pp. 263-278, 1952.

[37] R. M. Dunn Jr. and J. H. Mutti, International Economics, Routledge, London, UK, 5th edition, 2000.

[38] L. Edwards and O. Wilcox, "Exchange rate depreciation and the trade balance in South Africa," Prepared for South African National Treasury, 2003.

[39] H. G. Johnson, "The monetary approach to balance-ofpayments theory," Journal of Financial and Quantitative Analysis, vol. 7, no. 2, pp. 1555-1572, 1972.

[40] M. Miles, "The effects of devaluation on the trade balance and the balance of payments: some new results," The Journal of Political Economy, vol. 87, no. 3, pp. 600-620, 1979.

[41] R. Dornbusch, "Devaluation, money, and nontraded goods," The American Economic Review, vol. 63, no. 5, pp. 871-880, 1973.

[42] J. A. Frenkel and C. A. Rodriguez, "Portfolio equilibrium and the balance of payments: a monetary approach," The American Economic Review, vol. 65, no. 4, pp. 674-688, 1975.

[43] M. Bahmani, H. Harvey, and S. W. Hegerty, "Empirical tests of the Marshall-Lerner condition: a literature review," Journal of Economic Studies, vol. 40, no. 3, pp. 411-443, 2013.

[44] T. Demirden and I. Pastine, "Flexible exchange rates and the Jcurve: an alternative approach," Economics Letters, vol. 48, no. 3-4, pp. 373-377, 1995. 

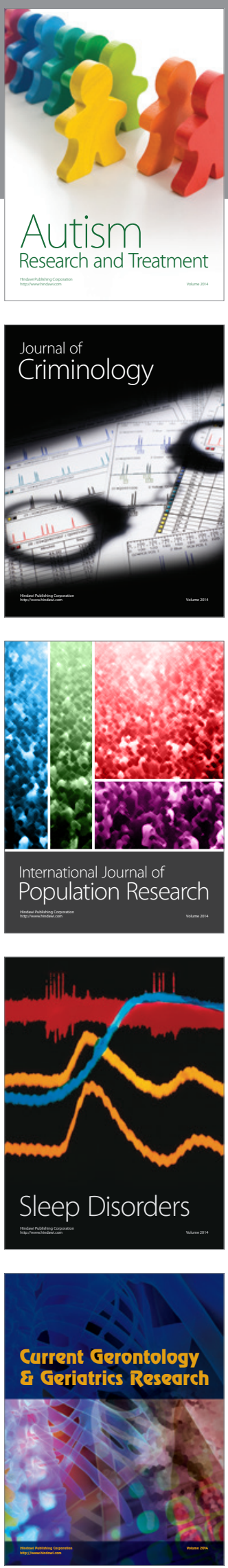
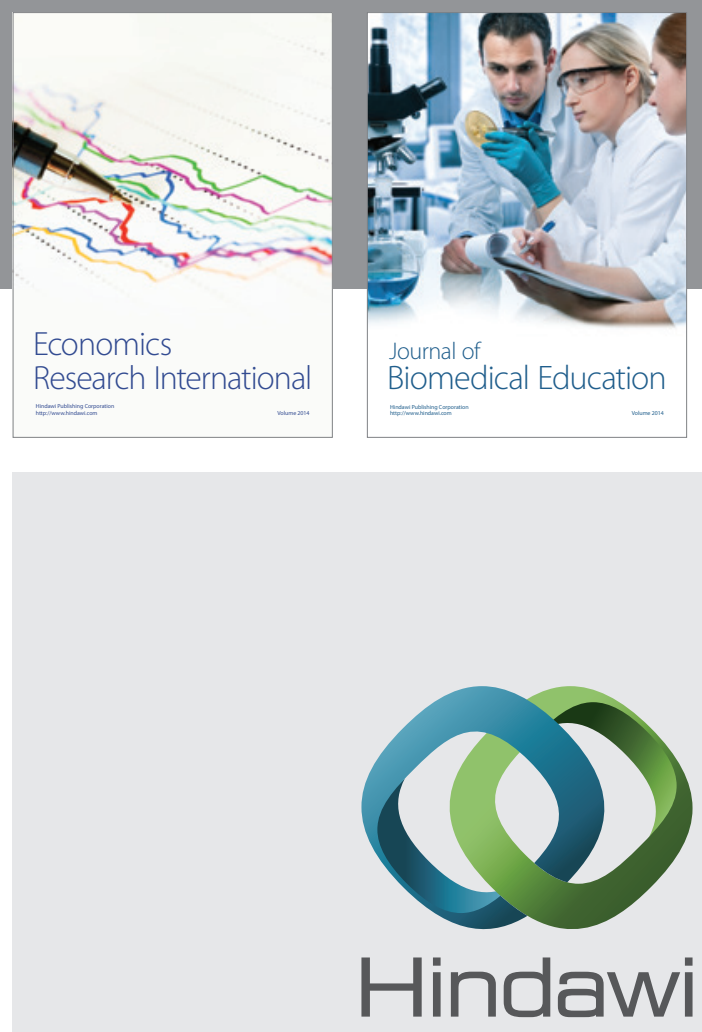

Submit your manuscripts at

http://www.hindawi.com
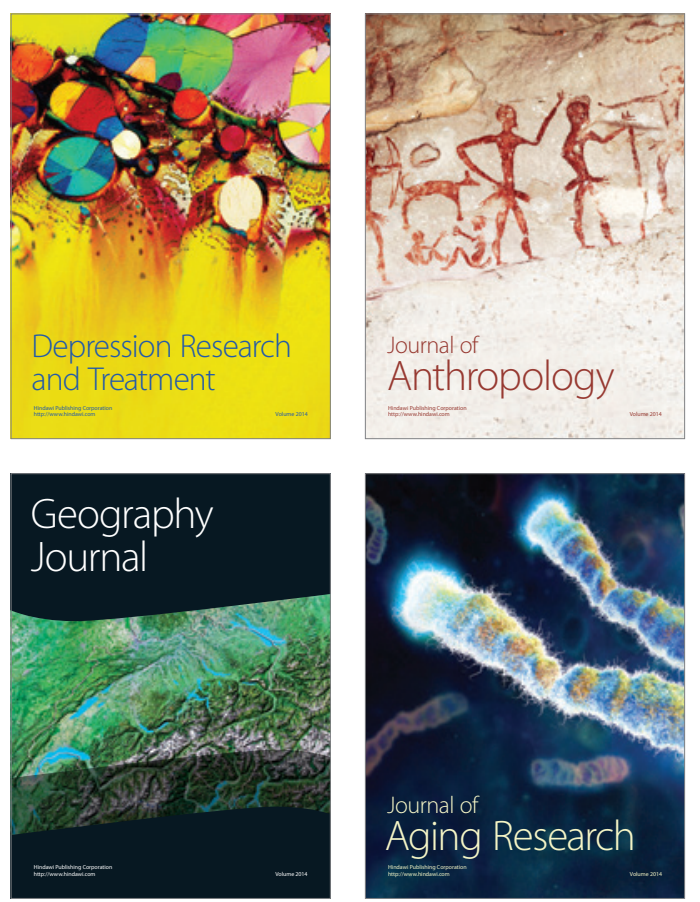
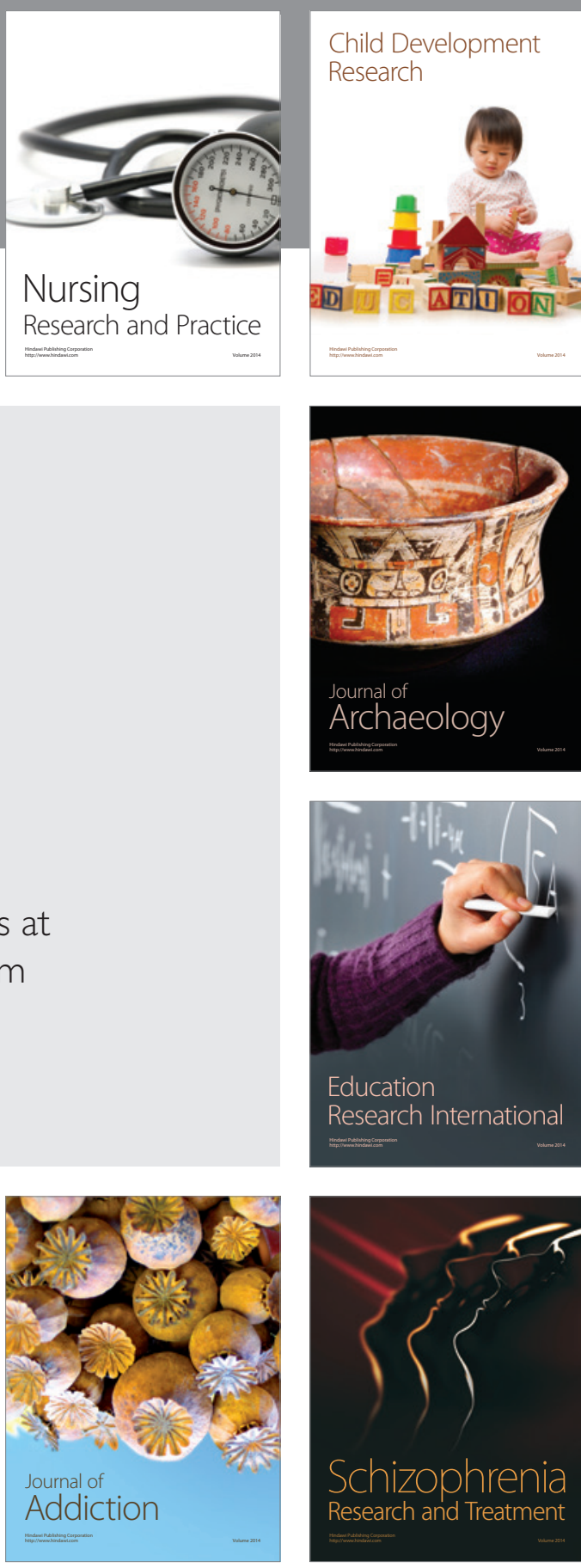

(D)
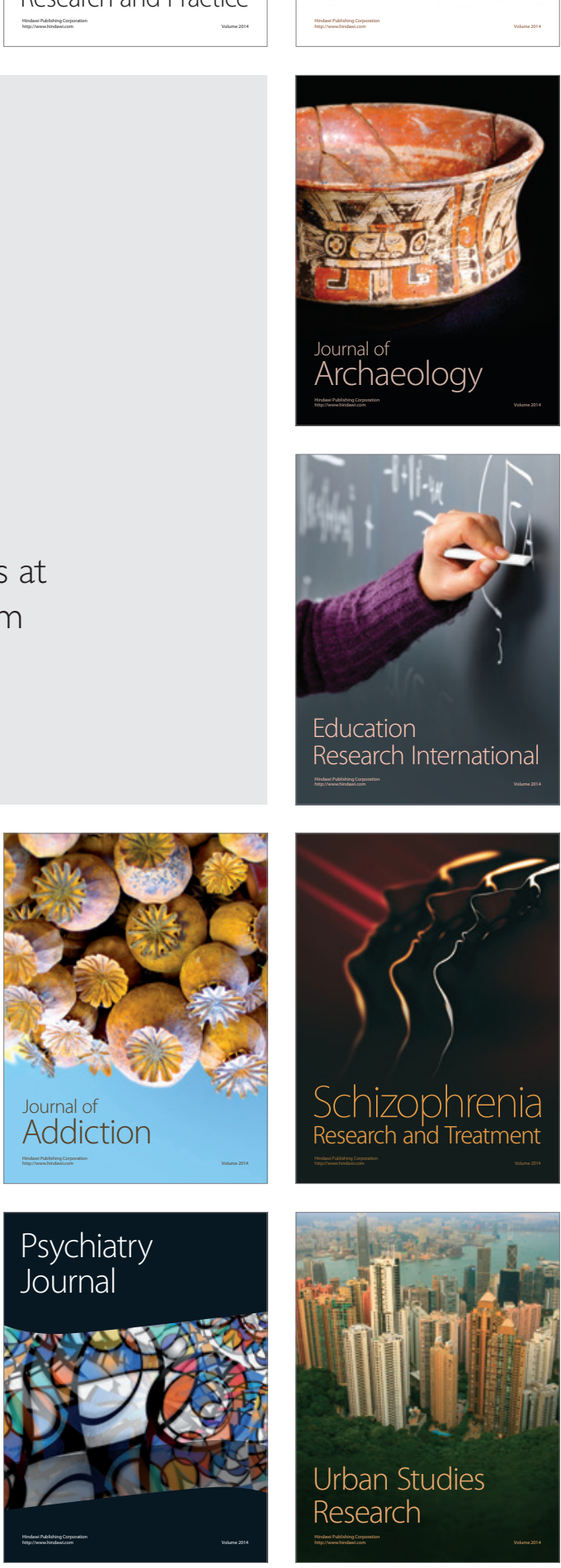